NASA Technical Memorandum 103142

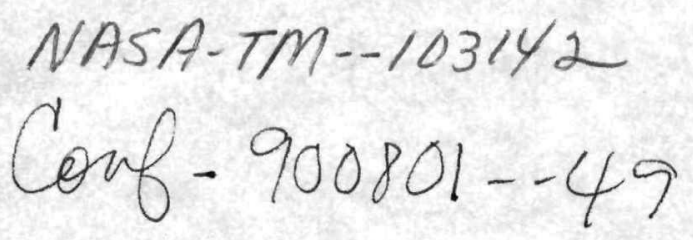

\title{
Programmatic Status of NASA's CSTI High Capacity Power Stirling Space Power Converter Program
}

\author{
James E. Dudenhoefer \\ Lewis Research Center \\ Cleveland, Ohio
}

Prepared for the

25th Intersociety Energy Conversion Engineering Conference cosponsored by the AIChE, SAE, ACS, AIAA, ASME, and IEEE Reno, Nevada, August 12-17, 1990

\section{DISCLAIMER}

This report was prepared as an account of work sponsored by an agency of the United States Government. Neither the United States Government nor any agency thereof, nor any of their employees, makes any warranty, express or implied, or assumes any legal liability or responsibility for the accuracy, completeness, or usefulness of any information, apparatus, product, or process disclosed, or represents that its use would not infringe privately owned rights. Reference herein to any specific commercial product, process, or service by trade name, trademark, manufacturer, or otherwise does not necessarily constitute or imply its endorsement, recommendation, or favoring by the United States Government or any agency thereof. The views and opinions of authors expressed herein do not necessarily state or reflect those of the United States Government or any agency thereof. 


\section{DISCLAIMER}

This report was prepared as an account of work sponsored by an agency of the United States Government. Neither the United States Government nor any agency Thereof, nor any of their employees, makes any warranty, express or implied, or assumes any legal liability or responsibility for the accuracy, completeness, or usefulness of any information, apparatus, product, or process disclosed, or represents that its use would not infringe privately owned rights. Reference herein to any specific commercial product, process, or service by trade name, trademark, manufacturer, or otherwise does not necessarily constitute or imply its endorsement, recommendation, or favoring by the United States Government or any agency thereof. The views and opinions of authors expressed herein do not necessarily state or reflect those of the United States Government or any agency thereof. 


\section{DISCLAIMER}

Portions of this document may be illegible in electronic image products. Images are produced from the best available original document. 
PROGRAMMATIC STATUS OF NASA'S CSTI HIGH CAPACITY

POWER STIRLING SPACE POWER CONVERTER PROGRAM

James E. Dudenhoefer

NASA Lewis Research Center

Cleveland, Ohio

An overview is presented of the NASA Lewis Research Center Free-Piston Stirling Space Power Converter Technology Development Program. This work is being conducted under NASA's Civil Space Technology Initiative (CSTI). The goal of the CSTI High Capacity Power element is to develop the technology base needed to meet the long duration, high capacity power requirements for future NASA space initiatives. Efforts are focused upon increasing system thermal and electric energy conversion efficiency at least fivefold over current SP-100 technology, and on achieving systems that are compatible with space nuclear reactors.

This paper will discuss the status of test activities with the Space Power Research Engine (SPRE). Design deficiencies are gradually being corrected and the power converter is now outputting $11.5 \mathrm{kWe}$ at a temperature ratio of 2 (design output is 12.5 $\mathrm{kWe}$. Detail designs have been completed for the $1050 \mathrm{~K}$ Component Test Power Converter (CTPC). The success of these and future designs is dependent upon supporting research and technology efforts including heat pipes, gas bearings, superalloy joining technologies and high efficiency alternators. This paper also provides an update of progress in these technologies.

\section{INTRODUCTION}

NASA Lewis Research Center (LeRC) started work on free-piston Stirling engines around 1977. Today, approximately 26 professionals are engaged in freepiston Stirling technology at LeRC. These projects include (a) Stirling Space Power Converters as part of NASA's new Civil Space Technology Initiative (CSTI) [1], and (b) the Advanced Stirling Conversion System (ASCS), to develop Stirling engine technology for terrestrial solar energy conversion. The ASCS program is funded by DOE with technical management provided by NASA LeRC through an interagency agreement with the Department of Energy (DOE) and Sandia National Laboratory (SNL). The ASCS project is based upon the use of current technology to demonstrate a system on-sun that is capable of generating $25 \mathrm{~kW}$ of electricity within DOE's long-term cost constraints [2]; NASA LeRC's involvement is due to the synergistic characteristics between space power and solar terrestrial power systems. These characteristics include high efficiency, low vibration, potential for long life and high reliability, and independence of heat source. The project should provide early meaningful life and reliability data to the DOE and NASA free-piston Stirling power converter programs. Further discussion and description of the ASCS program can be found in [2] and [3]. The discussion contained in this paper will be limited to NASA's CSTI High Capacity Power element.

\section{NEED FOR SPACE POWER}

NASA's space power technology historically has concentrated on systems delivering less than $10 \mathrm{~kW}$. Those power requirements have been met almost exclusively by photovoltaic (PV), RTG, and electrochemical storage systems. Over the next several decades, the amount of electric power in space is projected to grow immensely. Tomorrow's space platforms will require continuous power of hundreds of kilowatts; and some duty cycles will periodically consume many megawatts. These space platforms will include manned space stations, communication stations, surveillance platforms, and defensive weapons [6]. While future missions have not been defined in sufficient detail to specify precise power levels nor quality nor type of power, it is clear that future space power needs may be several orders of magnitude greater than anything that has been accomplished to date. The challenge for the space planner is formidable - to select power technologies that can meet the projected trends and adapt to multiple users. Developments in a newly proposed initiative, the Space Exploration Initiative (SEI), may provide the impetus to develop these first of a kind space power plants. President Bush in a July 20, 1989 message to the American people stated "I'm proposing a long range, continuing commitment, for the new century...back to the Moon. Back to the Future. And this time, back to stay." "And then... a journey into tomorrow... a journey to another planet... a manned mission to Mars." The President has provided the challenge; the Lewis Research Center, NASA's primary power technology center, has accepted the challenge. One space power system candidate for these bold missions is the free-piston Stirling power converter.

The free-piston Stirling is a rapidly emerging technology which has attracted considerable attention because of the successful $25 \mathrm{~kW}$ Space Power Demonstrator Engine (SPDE). A recent scaling study [7] indicates that it may be possible to build a 
free-piston Stirling engine/linear alternator system with up to $500 \mathrm{kWe}$ per cylinder. In perspective, less than 5 years ago it was considered a major achievement to build and successfully operate a 3 kWe free-piston Stirling engine. Stirling has sparked the imagination of designers of tomorrow's deliverable, reliable, and efficient power generators.

\section{ADVANCED STIRLING TECHNOLOGY}

The SP-100 program was established in 1983 by DOD, DOE, and NASA as a joint program to develop the technology necessary for space nuclear power systems for military and civil applications. During FY86 and 87, the NASA SP-100 Advanced Technology Program was devised to maintain the momentum of promising technology advancement efforts started during Phase I of SP-100 and to strengthen, in key areas, the chances for successful development and growth capability of space nuclear reactor power systems. In FY88, the Advanced Technology Program was incorporated into NASA's new Civil Space Technology Initiative (CSTI). The CSTI program was established to provide the foundation for technology development in automation and robotics, information, propulsion and power. The CSTI High Capacity Power Program builds on the technology efforts of the SP-100 program, incorporates the previous NASA SP-100 Advanced Technology project, and provides a bridge to the NASA Space Exploration Initiative (SEI).

The Stirling development program is expanding on the $650 \mathrm{~K}$ SPDE technology developed during Phase I of SP-100 and will proceed with the development of common design 1050 and $1300 \mathrm{~K}$ Stirling power converters. SP-100 systems studies have been conducted that show the growth potential of Stirling space power conversion systems when operated at peak temperatures of 1050 and $1300 \mathrm{~K}$ (Figure 1).

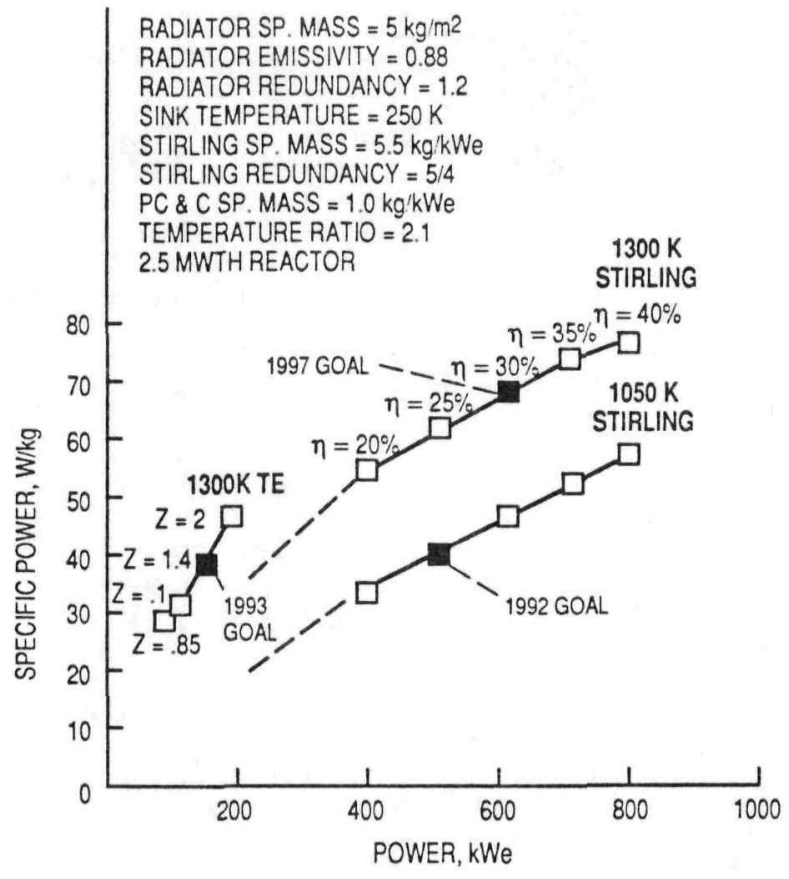

Figure 1 - EXTENDING SP-100 REACTOR POWER SYSTEMS CAPABILITY; THERMOELECTRICS (TE) AND STIRLING

The Stirling development program is illustrated pictorially on Figure 2. Component development in the areas of bearings, regenerators, heat pipe heat input, loss reduction and understanding, and temperature increases are being performed at the $12.5 \mathrm{kWe}$ size. When the appropriate technology

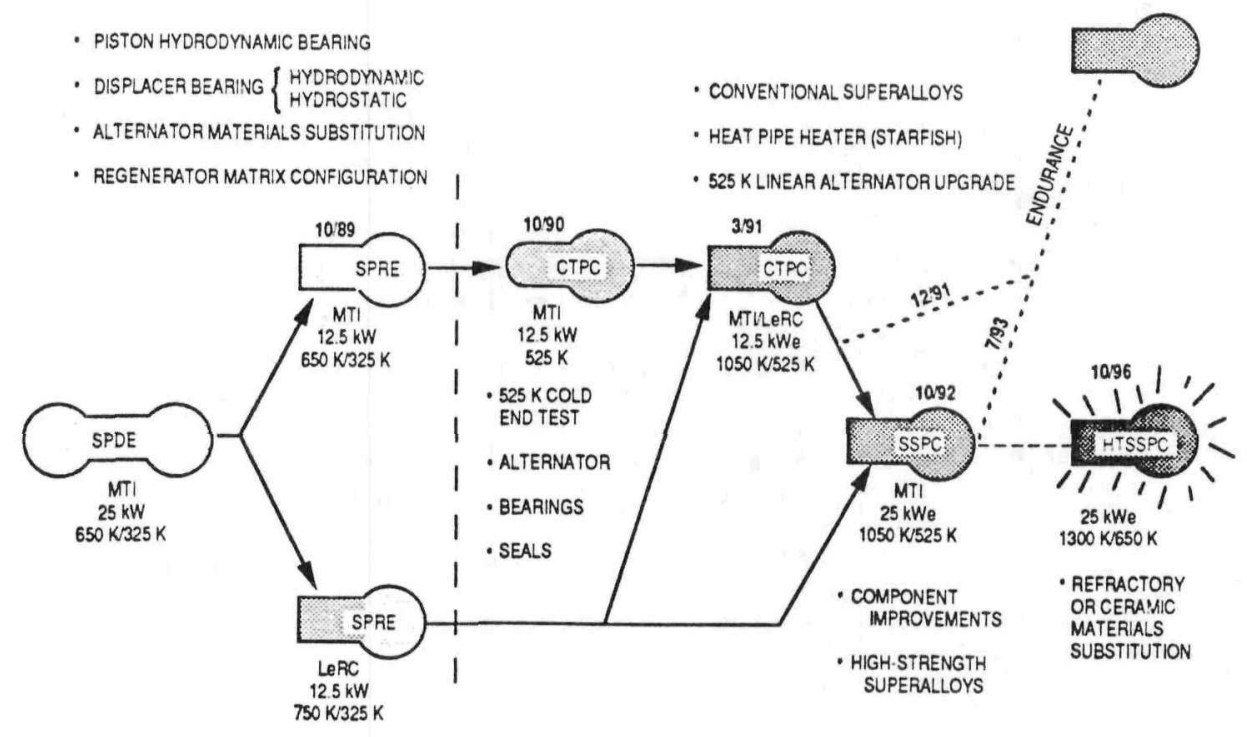

- LOSS UNDERSTANDING AND REDUCTION

- code deV. And validation

- dynamic balancing

- LOSS SENSITIVITY AND PERFORMANCE IMPROVEMENTS

Figure 2- EVOLUTION OF A HIGH TEMPERATURE (1300K) STIRLING SPACE ENGINE 
gains have been demonstrated, they will be incorporated into the $1050 \mathrm{~K}$ superalloy Stirling Space Power Converter (SSPC) at $25 \mathrm{kWe} / \mathrm{piston}$ to be tested in mid-FY93. The design goals for this power converter are given in Table 1. A design approach to meeting these goals is shown in Figure 3. The component technologies advancing to $1300 \mathrm{~K}$ (hot end) will also be accomplished in parallel, leading to the refractory Stirling Space Power Converter demonstration by the end of FY97, assuming funding continues beyond the current end date of FYg4.

\section{Table 1-1050K STIRLING SPACE ENGINE GOALS AND SPECIFICATIONS}

Balanced opposed configuration total power output, kWe $\ldots 50$ End of life power, kWe/Piston .................. 25 Efficiency, percent $\ldots \ldots \ldots \ldots \ldots \ldots \ldots \ldots \ldots \ldots,>25$

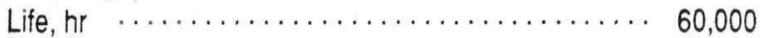
Hot side interface $\ldots \ldots \ldots \ldots \ldots \ldots \ldots \ldots$. Heat Pipe Heater temperature, $K \ldots \ldots \ldots \ldots \ldots . \ldots \ldots . \ldots . \ldots 1050$ Cooler temperature, $K \ldots \ldots \ldots \ldots \ldots \ldots \ldots \ldots \ldots . \ldots \ldots$ Vibration - casing peak-peak, $\mathrm{mm} \ldots \ldots \ldots \ldots \ldots \ldots<0.04$

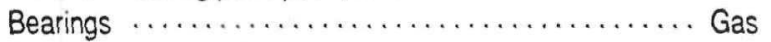

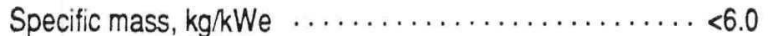

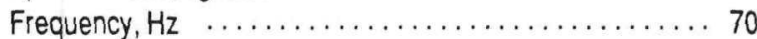

Pressure, MPa $\ldots \ldots \ldots \ldots \ldots \ldots \ldots \ldots \ldots \ldots . \ldots \ldots . \ldots \ldots$

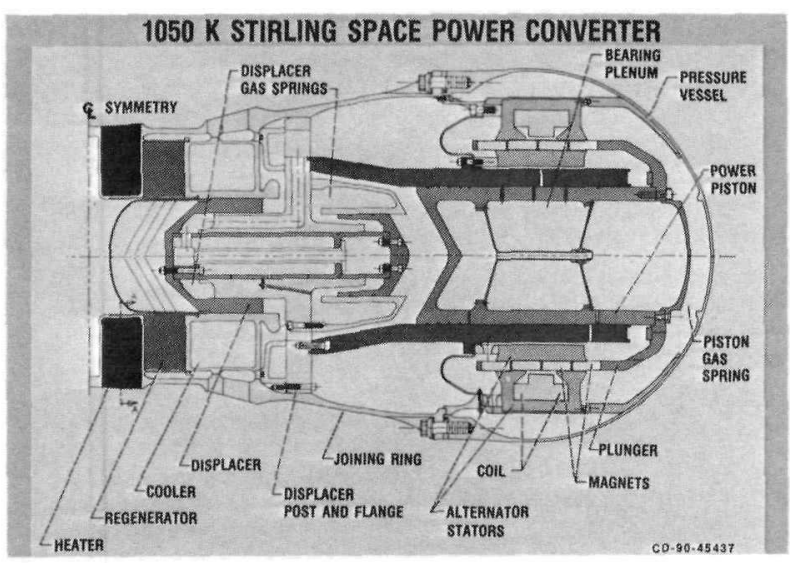

Figure 3 - PRELIMINARY DESIGN OF 1050K STIRLING SPACE POWER CONVERTER
PROGRESS HIGHLIGHTS SPDE/SPRE

SPDE

In October of 1986 the $650 \mathrm{~K}$ SPDE developed $25 \mathrm{~kW}$ of engine P-V power. Results of this engine testing are discussed in [4] through [6]. After this successful demonstration the engine was cut in half. One half is undergoing testing at NASA Lewis and the other half at the contractor's site, Mechanical Technology Inc. (MTI) in Latham, New York. These power converters are now called Space Power Research Engines (SPRE) and serve as test beds for evaluation of key technology areas such as linear alternators, and hydrostatic and hydrodynamic gas-bearings. Figure 4 shows one of these SPRE research converters in a NASA Lewis test cell. The following discussion will highlight progress in each of these technical areas:

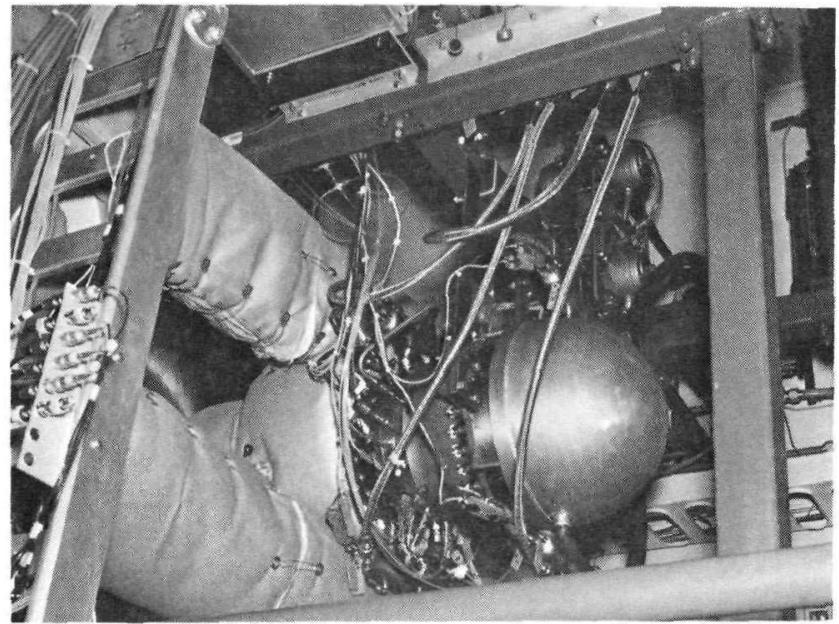

FiquPe 4. SPRE I INSTALLED IN THE NASA FACILITY

SPRE - Linear Alternator

Recent testing at MTI of the SPRE, with a nonmagnetic alternator support structure substituted for a magnetic structure, verified the expectation of a substantial increase in alternator efficiency. At design point operating conditions of 150 bar pressure, a temperature ratio of two, and $10 \mathrm{~mm}$ piston amplitude, an alternator efficiency of greater than $90 \%$ was achieved. Previously, with the magnetic support structure, a design point alternator efficiency of only $72 \%$ was measured. Electrical power output increased from $8 \mathrm{kWe}$, with the magnetic structure, to $11.2 \mathrm{kWe}$ - a $40 \%$ increase. The measured alternator efficiency and electrical output power, plotted as a function of piston amplitude, are shown in Figure 5.

The above improvement in SPRE performance was anticipated since prior work, performed by MTI, had indicated that an alternator efficiency of greater than $90 \%$ should be achievable. This work included detailed finite element analysis, alternator bench tests, and linear alternator dynamometer tests [9].

The goal of the recent SPRE test was, therefore, to demonstrate the anticipated high alternator efficiency in a running engine. This goal was successfully achieved. 
SPRE - Bearings

To realize the long life potential of the freepiston Stirling power converter, it is necessary to eliminate friction, wear, and the need for lubrication systems. Non-contacting bearings have demonstrated that they can provide stable piston and displacer support.
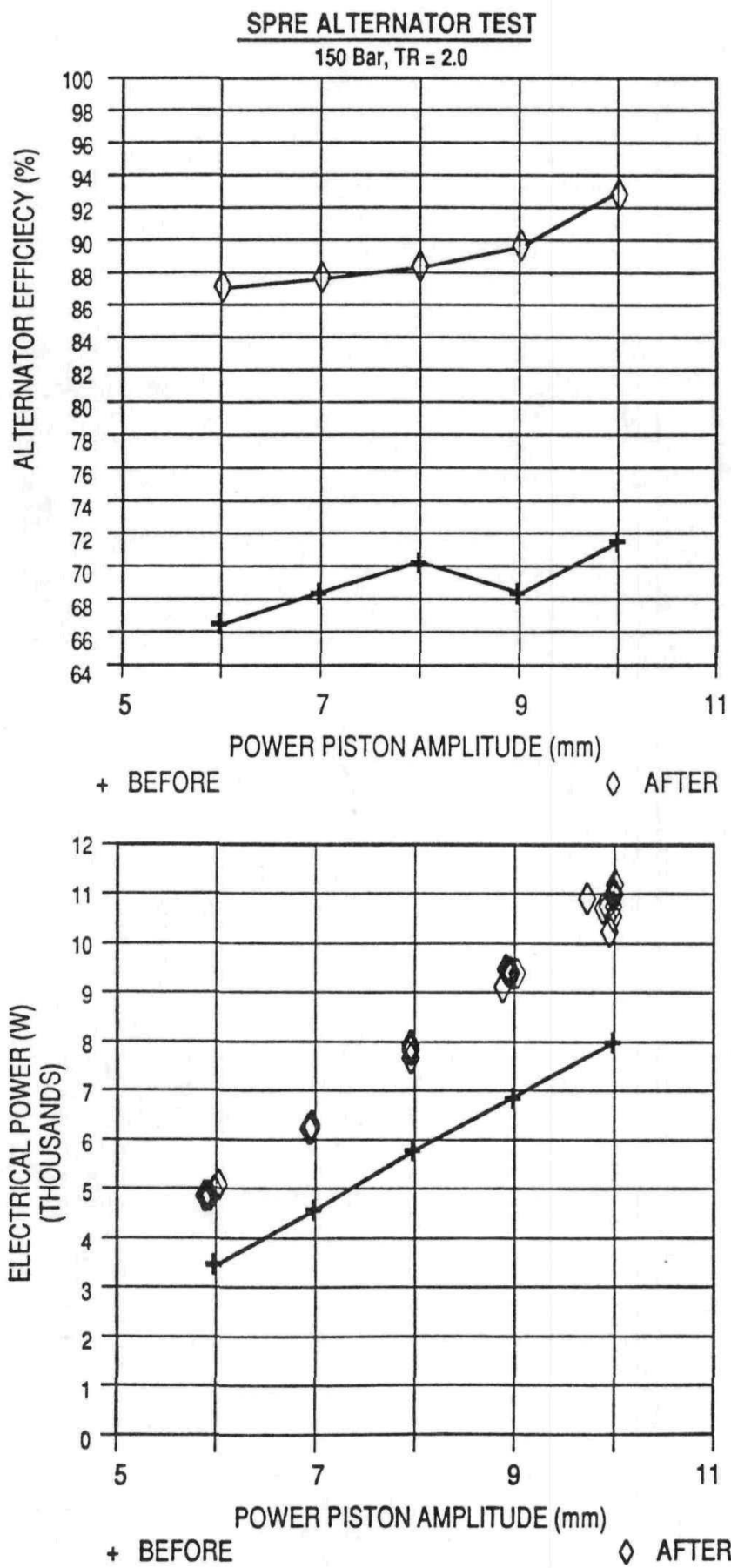

\section{Figure 5 - SPRE TEST RESULTS WITH IMPROVED LINEAR ALTERNATOR}

Three types of bearing systems have been considered to date:

(1) hydrostatic, (2) hydrodynamic, (3) magnetic

The hydrostatic bearing has been successfully demonstrated in the SPRE on both the displacer and the power piston. The term "hydrostatic" indicates that the pressure profile, which generates the load carrying capacity, is primarily the result of a bearing pressure supply. Gas is supplied from a high pressure source (higher than engine mean pressure) into the bearing clearance between the cylinder and the reciprocating piston. The advantages of the hydrostatic bearing are its relatively high stiffness, its high stability, and its demonstrated operation. The disadvantages are its mechanical complexity and its impact on engine efficiency. Mechanical complexity arises from the need for numerous drillings, orifices and supply and drain galleries. Engine efficiency is reduced because of the high-pressure amplitude requirement in the gas springs (about 7 bar) which results in significant thermal hysteresis and seal leakage loss.

The hydrodynamic bearing has also been successfully demonstrated in the SPRE but only on the power piston. Hydrodynamic bearings have the potential to simplify the bearing mechanical arrangement and reduce losses. Loss reduction occurs due to reduced seal leakage, gas spring hysteresis, and porting losses. The bearing primarily allows for lower gas spring pressure designs not possible with hydrostatic bearings. The bearing load capacity (bearing pressure distribution) is generated by rotational motion of the bearing journal and therefore does not require a pressure source; the bearing does, however, require an additional spin motor and motor controller. The disadvantages of the hydrodynamic bearing are its susceptibility to whirl instability and increased part count due to the spin motor and controller. Mechanical Technology Incorporated (MTI), implemented a hydrodynamic gas bearing on the power piston of the SPRE power converter. Tests with piston reciprocation showed that plain journal bearings were inherently unstable; pistons modified with stabilizing surface treatment called herringbone grooves achieved only marginal stability; but plain journal bearings with bearing drain grooves to mean pressure to isolate the bearing length from time-varying pressure gradients showed stable operation at design conditions out to the maximum $20 \mathrm{~mm}$ stroke [11].

A comparison of hydrostatic versus hydrodynamic bearing losses is shown in Table 2. While the hydrodynamic bearing appears to have an efficiency advantage over the hydrostatic, additional studies are needed before committing to a bearing design. The hydrodynamic bearing has not yet been tested on the SPRE displacer and some concern exists about displacer hydrodynamic bearing stability in space. Hydrodynamic bearing stability increases as bearing load increases; in space, displacer bearing loading is expected to be low. The next power converter, the CTPC, is therefore being designed to accommodate both hydrostatic and/or hydrodynamic bearings.

A third type of non-contacting bearing is the magnetic bearing. Although magnetic bearings have not 
yet been tested on the SPRE, this style bearing has been successfully implemented by Goddard Space Flight Center in Stirling cryocoolers for space [12]. While it is assumed that magnetic bearings will be large and require complex dynamic control systems, a study is being implemented to assess trade-offs for the high capacity space power application.

\section{Table 2 - HYDRODYNAMIC VERSUS HYDROSTATIC BEARING}

(Loss (in W) at 150-bar Mean Pressure and 20-mm Stroke)

\begin{tabular}{|l|r|c|}
\hline \multicolumn{1}{|c|}{ Loss Mechanism } & Hydrostatic & Hydrodynamic \\
\hline \hline Seals & 176 & 176 \\
Gas Spring/Porting & 1500 & 320 \\
Rotation-Induced Losses (viscous, & 0 & 69 \\
windage, and alternator eddy & & \\
$\quad$ current) & & 130 \\
Spin Motor Power & 0 & 0 \\
Bearing Flow Power & 50 & 695 \\
\hline \hline Total & 1726 & \\
\hline
\end{tabular}

PROGRESS HIGHLIGHTS - SUPPORTING RESEARCH AND TECHNOLOGY

\section{Magnetics Test Rig}

Technical concern has been expressed about operating permanent magnet linear alternators near their upper temperature limits. It is anticipated, for example, that the $\mathrm{Sm}_{2} \mathrm{CO}_{17}$ linear alternator, which has an upper operating temperature limit of about $575 \mathrm{~K}$ will be operating normally at about $550 \mathrm{~K}$. Obviously, for the $1300 \mathrm{~K}$ power converter operating at a temperature ratio of 2, either another type of linear alternator must be chosen or a separate alternator cooling loop must be implemented. Both solutions could produce a significant mass penalty. The LeRC Power Systems Integration Office has been conducting systems analysis studies based upon information available from the recently completed Stirling scaling study [7] and other data emanating from the Stirling High Capacity Power Program. Capitalizing on trends shown in Figure 6 , a third alternative might now be considered. Figure 6 indicates that only a small system mass penalty may be incurred for using somewhat higher power converter temperature ratios. This may allow use of the current alternator configuration without requiring a separate alternator cooling loop. While this option could hold promise - providing the scaling inputs and assumptions are shown to be correct - the samarium-cobalt magnets are still operating close to their upper operating limits. Having recognized the need for high temperature magnet information, a test facility was developed (see Figure 7) to characterize samples of magnets from a variety of vendors at power converter operating temperatures. Besides generating B-H plots at temperature, this facility can also conduct magnet life testing at temperature. Measurements have been made on magnet samples from 5 vendors at $475 \mathrm{~K}$ and are now beginning at $575 \mathrm{~K}$. Results will be published in the near future.

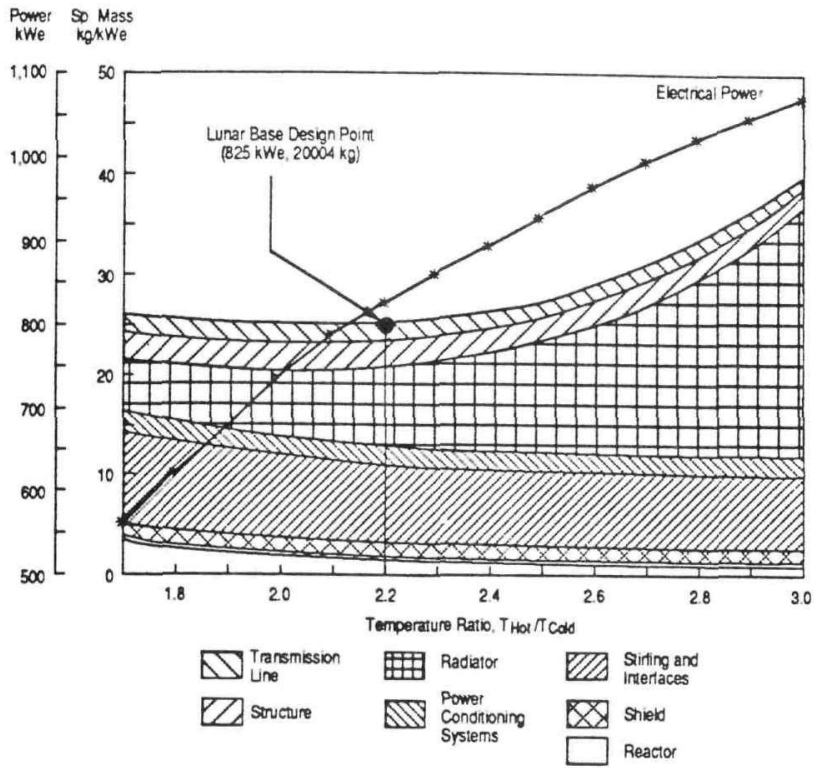

Figure 6 - STIRLING SYSTEM COMPONENT MASS AND POWER VARIATION WITH TEMPERATURE RATIO

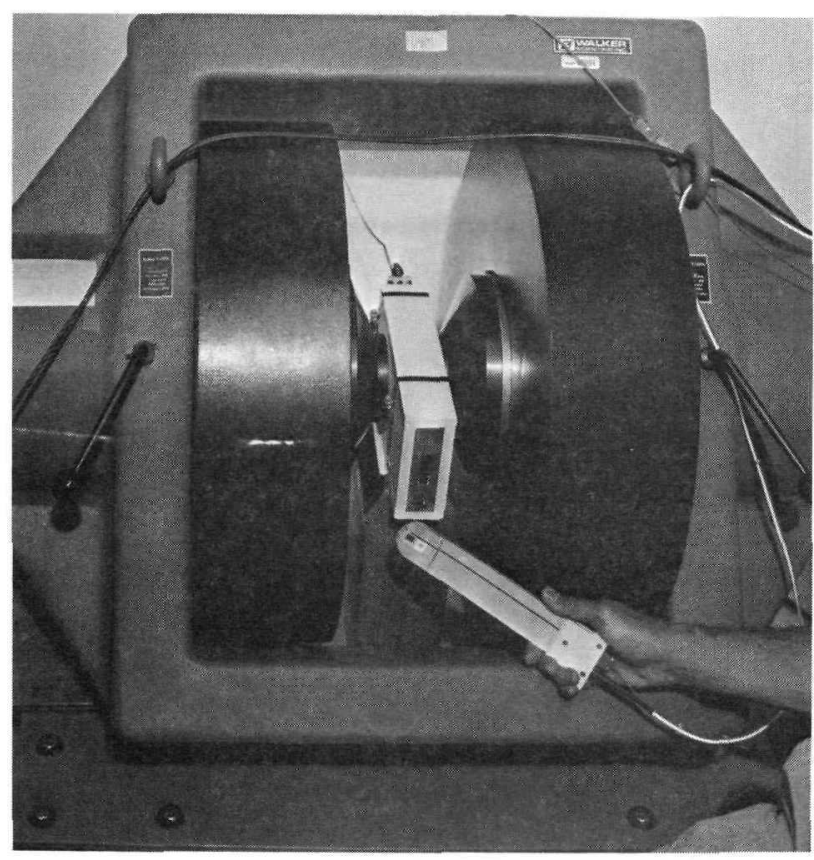

Figure 7 - MAGNETICS TEST RIG

Heat Pipes

Testing is on-going at LeRC with the HP-1000 power converter. This $1 \mathrm{~kW}$ converter uses a sodium heatpipe heater head to transport heat energy from radiant heaters to the hot end of the Stirling power converter [10] (Figure 8 ). During this past 


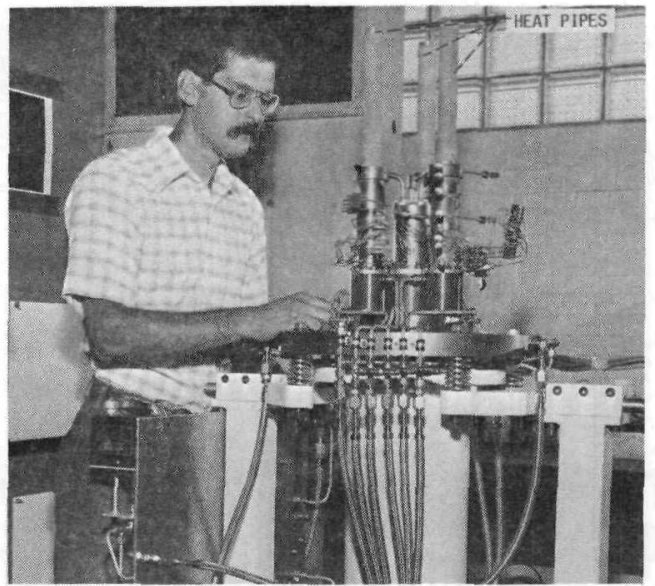

Figure 8 - HP-1000 HEAT PIPE STIRLING POWER CONVERTER TEST FACILITY

year, tests have been successfully conducted to hot end temperatures of $1050 \mathrm{~K}$ with the heat pipes operating against gravity. There were no surprises; the heat pipes performed as predicted, yielding good performance from the HP-1000. Testing will continue with the HP-1000 inverted, thus placing the heat pipes in the gravity assist position. Overall results will be published in the near future. Because very little information exists regarding the use of heat pipes with Stirling power converters, successful operation of this LeRC facility has given Stirling designers the confidence they need to press on with even more innovative mass and joint saving heat pipe designs.

The Starfish Heater Head is a novel heater concept proposed by MTI. Development of this concept has continued through the detail design stage. The heater, which includes a sodium heat pipe interface to the system heat source will operate at $1050 \mathrm{~K}$. It is the most critical technological development of all the CTPC heat exchangers. The other heat exchangers, the regenerator and cooler, are of a more conventional design like those used in existing stirling engines. A photograph of a model of the Starfish Heater Head is shown in Figure 9.

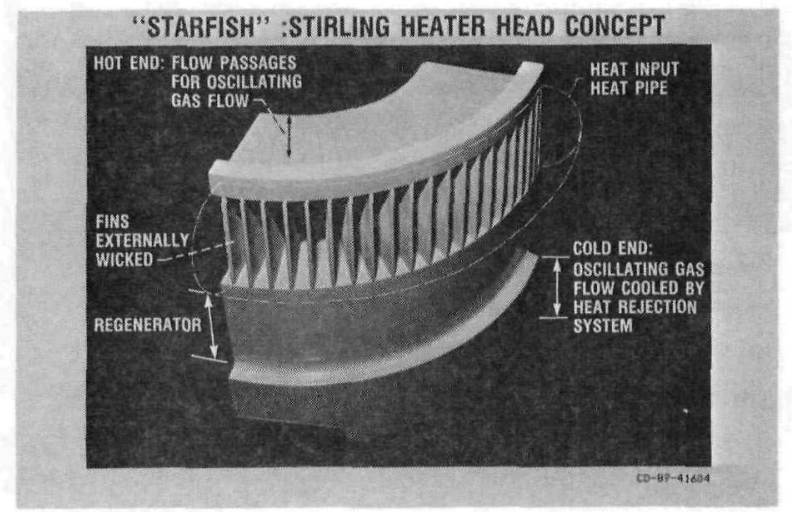

Figure 9- STARFISH HEATER HEAD
The Starfish Heater Head will have approximately 1,400 gas flow passages and 50 heat pipe condenser regions which transport heat from the system heat source to the helium working fluid of the power converter. The advantage of the Starfish Heater Head design over a conventional heater is that the heat exchange surfaces are formed without weld or braze joints. In comparison, a conventional tubein-shell heater head would require at least 2,800 weld or braze joints. The entire Starfish Heater Head will be fabricated by electrical discharge machining (EDM) and electrolytic machining (STEM) processes. Only three weld joints are then required to join the heater head to the heat pipe and the remainder of the engine.

The final heater head will be fabricated from Udimet 720 alloy in order to achieve the 60,000 hour life goals of the contract. Udimet 720 is very difficult to weld. The alloy will crack when joined by conventional fusion welding techniques and therefore must be joined by friction welding or liquid phase diffusion bonding processes which do not melt the alloy as the joint is formed. The first CTPC heater head will be fabricated from a more easily weldable alloy, Inconel 718, which has a relatively short creep rupture life in comparison to Udimet 720 . The Inconel 718 heater head will be used as proof-of-concept to establish engine performance while the welding process is defined for the three Udimet 720 weld joints.

Since the Starfish Heater concept was first selected, gas passage holes have been successfully formed in fins (see Figure 9) by the STEM process. The detail design of the entire sodium heat pipe, including the evaporator section, has been completed by Thermacore, Inc.

Loss Reduction and Understanding

For several years, NASA and other U.S. Government agencies have been funding experimental and analytical efforts to improve the understanding of Stirling thermodynamic losses. NASA's objective is to improve Stirling power converter design capability to support the development of new engines for space power. The current program at LeRC involves 11 contracts and grants. Experimental and analytic results continue and are reported in [13].

\section{CONCLUDING REMARKS}

During its relatively short evolutionary history, free piston Stirling (FPS) has demonstrated remarkable progress. Uitimate programmatic goals are still considered achievable as no technology barriers have been identified which might impede success. The program moves with confidence into the next phase of technology development as the CSTI free piston Stirling evolves from current $800 \mathrm{~K}$ technology to higher temperature $1050 \mathrm{~K}$ technology. Detail designs have been completed and approved; metal is being cut; and testing of the CTPC cold end, at temperature $(525 \mathrm{~K})$, is expected in the Fall of this year.

Systems studies continue to show the mass and size reduction, survivability, and transportation cost savings potential of dynamic space power systems as 
compared to static systems. Free piston Stirling continues to be identified as the most efficient dynamic power system with the lowest system specific mass in the SP-100 power range.

\section{REFERENCES}

[1] Office of Aeronautics and Space Technology, "Civil Space Technology Initiative...A First Step," NASA TM-100949, 1988.

[2] Shaltens, R.K., "Comparison of Stirling Engines for Use With a $25 \mathrm{~kW}$ Dish-Electric Conversion System," NASA TM-100111, DOE/NASA/33408-2, 1987.

[3] Shaltens, R.K. and Schreiber, J.G., "Comparison of Conceptual Designs for $25 \mathrm{kWe}$ Advanced Stirling Conversion Systems for Dish Electric Applications, " NASA TM-102085, DOE/NASA/ 33408-3, 1989.

[4] Dochat, G.R., "Free-Piston Stirling Engine For Space Power, " Proceedings of the TwentySecond Automotive Technology Development Contractor's Coordination Meeting, Society of Automotive Engineers, Warrendale, PA, 1984, pp. 209-213.

[5] Slaby, J.G., "Overview of Free-Piston Stirling SP-100 Activities at the NASA Lewis Research Center," NASA TM-87224, DOE/NASA/ $1005-8,1986$.

[6] Slaby, J.G., "Free-Piston Stirling Technology for Space Power, " NASA TM-101956, 1989.

[7] Jones, D., "Free-Piston Stirling Engine Scaling Study," Proceedings of the 25th IECEC, to be published, 1990.

[8] Winter, J.M., "CSTI High Capacity Power," NASA TM-102059, 1989.

[9] Rauch, J.S., Bolton, R.J. and Short, H.F., "SPRE Alternator Dynamometer Test Report," NASA CR-182251, 1990.

[10] Schreiber, J.G., "Initial Characterization of a Modular Heat Exchanger With an Integral Heat Pipe," NASA TM-102097, 1989.

[11] Spelter, S. and Dhar, M., "Space Power Research Engine Power Piston Hydrodynamic Bearing Technology Development," NASA CR182136, 1989.

[12] Stolfi, F., Goldowsky, M., Keung, C., Knox, L., Lindale, E., Maresca, R., Ricciardelli, J. and Shapiro, P., "Design and Fabrication of a Long-Life Stirling Cycle Cooler for Space Application," PL-11-CR83-0307, 1983.

[13] Tew, R.C. and Thieme, L.G. and Dudenhoefer, J.E., "Recent Stirling Engine Loss Understanding Results, " Proceedings of the 25th IECEC, to be published, 1990. 


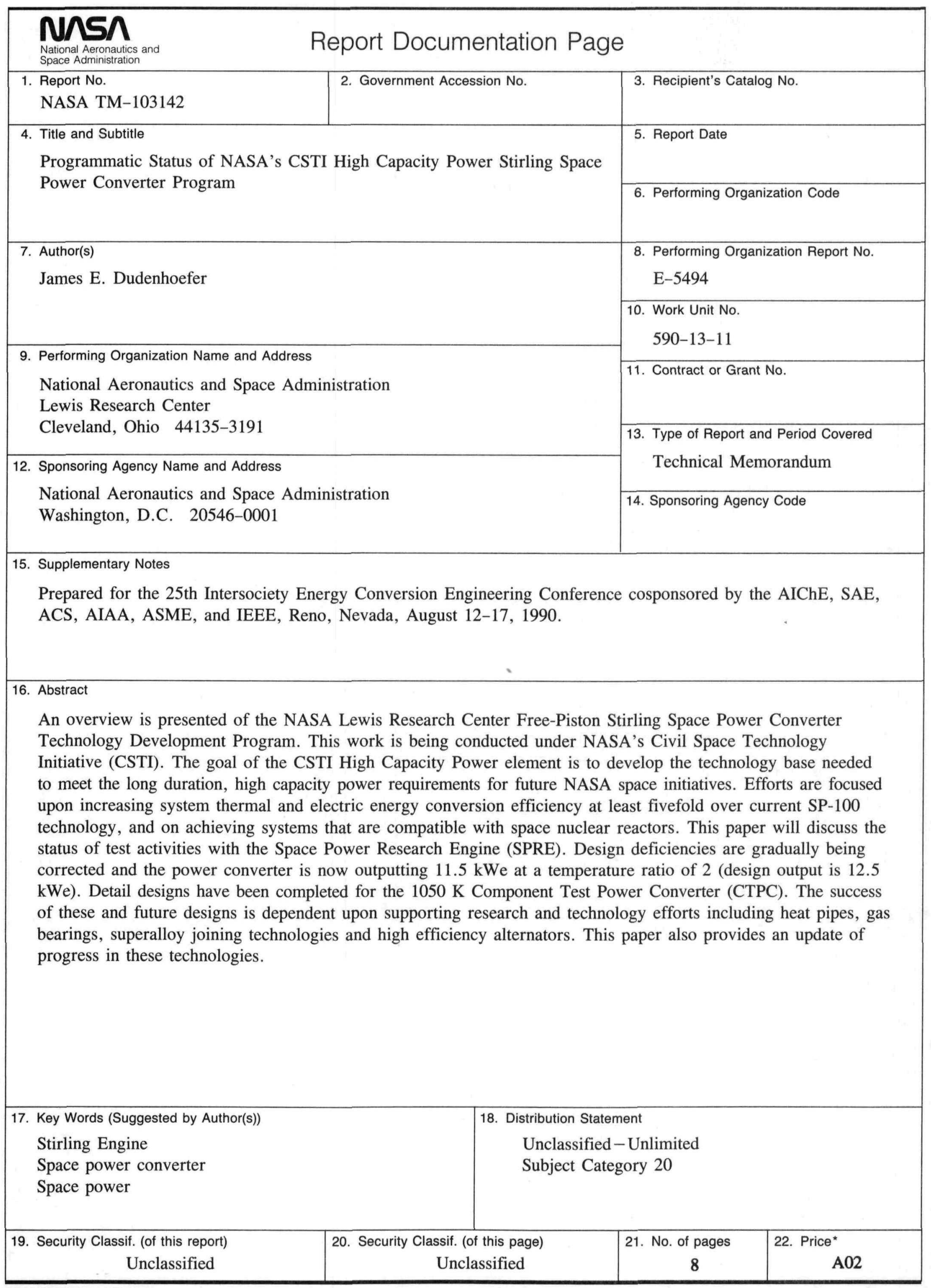


National Aeronautics and Space Administration

Lewis Research Center

Cleveland, Ohio 44135

Otficial Business

Penalty for Private Use $\$ 300$
FOURTH CLASS MAIL

ADDRESS CORRECTION REQUESTED

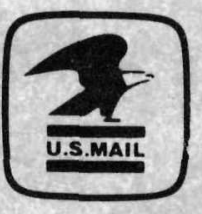

Postage and Fees Paid

National Aeronautics and

Space Administratıon

NASA 45 